\title{
Clinical Evaluation of Mizaj (Temperament) in Patients of Hypothyroidism
}

\author{
Shiekh Zahoor Ahmad ${ }^{1 *}$, Arsheed Iqbal ${ }^{1}$, Haider Ali Quraishi ${ }^{1}$, Afroza Jan ${ }^{2}$, Naquib ul Islam ${ }^{3}$, Shamim Ahmad Rather ${ }^{4}$
}

${ }^{1}$ PG Scholars, (Department of Moa'lajat), Regional Research Institute of Unani Medicine, University of Kashmir, Hazratbal, Srinagar Jammu \& Kashmir, India

${ }^{2}$ Assistant Professor Physiology, Government Unani Medical College, Ganderbal, Srinagar Jammu \& Kashmir, India

${ }^{3}$ Professor, (Department of Moa'lajat), Regional Research Institute of Unani Medicine, University of Kashmir, Hazratbal, Srinagar Jammu \& Kashmir, India

${ }^{4}$ Reader, (Department of Moa'lajat), Regional Research Institute of Unani Medicine, University of Kashmir, Hazratbal, Srinagar Jammu \& Kashmir, India

DOI: $10.36348 /$ sijtcm.2021.v04i02.001

| Received: 09.01.2021 | Accepted: 20.01.2021 | Published: 19.02.2021

*Corresponding author: Shiekh Zahoor Ahmad

\section{Abstract}

Unani system of medicine is based on the theory of Mizaj and Akhlat which is considered as the basics of Unani therapeutics. Mizaj is defined as the admixture of four humours (Akhlat), the quantity and quality of which determines the particular Mizaj of an individual. Every individual has its own unique Mizaj (temperament), hence reacts to various internal and external stimuli viz.air, water, diet, drug, climate, emotions, body reactions etc. differently according to temperament. Hence, Mizaj plays an important role in diagnosis and treatment of any disease. Since, Hypothyroidism is considered as one of the most common endocrine disorders in which patient has somnolence, fatigue, cold intolerance, constipation, loss of libido, gain in weight etc. According to the classical texts of Unani Medicine, it is the concentration, quality and quantity of humours which forms the base and cause of health and disease in an individual. As per Unani doctrine, Mar'd (Disease) is caused either due to Su' Mizaj (abnormal temperament), Su'tarkib( abnormal composition/structure) or Taffaruk Ittesal (discontinuity). This study was conducted at Regional Research Institute of Unani Medicine, University of Kashmir ,Srinagar Jammu \& Kashmir to evaluate the Mizaj (Temperament) of patients of Hypothyroidism. Out of 60 patients enrolled for the study, 52 (86.6\%) were Balghami, 03 (5\%) were Damwi, 05 (8.3\%) were Safravi and none was of Sawdawi Mizaj. Thus, it was evident that Hypothyroidism is more common in Balghami Mizaj patients.

Keywords: Mizaj, Humours, Unani, Hypothyroidism, Mar'd, Temperament.

Copyright () 2021 The Author(s): This is an open-access article distributed under the terms of the Creative Commons Attribution 4.0 International License (CC BY-NC 4.0) which permits unrestricted use, distribution, and reproduction in any medium for non-commercial use provided the original author and source are credited.

\section{INTRODUCTION}

Hypothyroidism in the simplest terms can be defined as deficient production of thyroid hormone. Primary hypothyroidism indicates decreased secretion of thyroid hormone by factors affecting the thyroid gland itself. A decrease in serum concentrations of thyroid hormone causes an increased secretion of Thyroid Stimulating Hormone (TSH), thus resulting in elevated serum TSH concentration [1-9].

The incidence of Hypothyroidism in India has a female to male ratio of $6: 1$.

The thyroid gland secretes two significant hormones, thyroxine and triiodothyronine commonly called as T4 and T3 that has the profound effect of increasing the metabolic rate of the body [10-13].

Hypo secretion of thyroid hormone decreases all the physiological activity of the body and causes loss of appetite, constipation, decreased heart rate, decreased respiration, weight gain, somnolence, loss of libido, menorrhagia, etc. which closely resemble with the symptoms and signs of su' mizaj barid (impaired cold temperament) of Unani system of medicine [14-21].

Hypothyroidism can affect all organ systems, and these manifestations are largely interdependant of the underlying disorder but are a function of the degree of hormone deficiency. The clinical features include somnolence, fatigue, weight gain, cold intolerance, loss of appetite, constipation, hoarseness of voice, loss of libido, menorrhagia, polymenorrhea, dyslipidaemia, polyarthalgias, myalgias, decreased reflexes etc $[1,22$, 23-33].

Classical texts of Unani medicine have not described qillatt-i-ifraze darqia (hypothyroidism) directly, but the clinical features resemble with the symptoms and signs of Su'-Mizaj Barid/Su' Mizaj Balghami (impaired cold temperament/impaired 
phelgematic temperament) which has been discussed in classical texts in detail. As per the fundamentals of Unani system of medicine, Mar'd (disease) occurs due to Su'- Mizaj (impaired temperament), Su'-Tarkib (abnormal composition/structure) or Tafarruq-i-Ittisal (discontinuity). Su'-Mizaj (impaired temperament) has again been divided into Su'-Mizaj Harr (impaired hot temperament), Su'-Mizaj Barid (impaired cold temperament) Su'- Mizaj Ratb (impaired moist temperament), Su'-Mizaj Yabis (impaired dry temperament). The clinical features of Su'-Mizaj Barid (impaired cold temperament) include tahubbuj (puffiness), kathra al-buzaq (excessive salivation), kathra al-nawm (excessive sleep), kusul-wa-mandgi (somnolence), du'f al-Ishtiha (loss of appetite), kund zehni (loss of intellectual functions), du'f al-bah (loss of libido), nabd layyinn-wa-bati (pulsus mollis and pulsus tardus) [14-21].

The above discussed symptoms and signs of su'- mizaj barid /su'- mizaj balghami (impaired cold temperament/impaired phelgematic temperament) somehow resemble with the clinical features of hypothyroidism described in modern medicine.

In this context, a hypothesis was drawn that su'- mizaj barid /su'- mizaj balghami (impaired cold temperament/impaired phelgematic temperament) may be interpreted with the clinical features of hypothyroidism using modern scientific parameters.

\section{OBJECTIVES OF THE STUDY}

The objectives of the study are:-

- To know the Mizaj of patients of Qillat-iIfraze-Darqia Ibtidai (Primary Hypothyroidism).

- To evaluate the role of Mizaj in the patients of Qillat-i-Ifraze-Darqia Ibtidai (Primary Hypothyroidism).

\section{METHODOLOGY}

The study was conducted on a sample size of 60 patients in the Deptt. Of Moa'lajat, Regional Research Institute of Unani Medicine Srinagar Jammu \& Kashmir from November 2018-February 2019. The criteria for selection of patients was by history taking,clinical examination and investigations

\footnotetext{
Inclusion Criteria

- Clinically diagnosed patients of Hypothyroidism.

- $\quad$ Sex-Male, Female, Transgender.

- Patient in age group of 20 to 60 years.

- Willingness to sign the informed consent, follow the protocol and participate in clinical trial voluntarily
}

\section{Exclusion Criteria}

- Patients below 20 and above 60 years.

- Pregnancy and Lactation

- Patients on iodine containing vitamins or minerals

- Patients who have undergone thyroid surgery, taken radioactive iodine therapy

- Diabetes mellitus

- Renal dysfunction

- Patients who fail to give consent

- All complicated cases of hypothyroidism

- Liver diseases

- Gastrointestinal diseases(Peptic ulcer disease)

- IHD and hypertension

The source for selection of cases was the Outpatient department of RRIUM Srinagar. History and clinical examination was the basis for enrolling patients for the study. Patients were asked complete history, present and past and general physical and systemic examinations were carried out. Specially designed case record forms were used for the recording of the details of the patients which included name, age, sex, address, occupation, marital status, socio economic status, dietary habits, educational background, income, chief complaints, history of present illness, past history, family history, treatment history etc. General examination include pulse, BP, temperature, respiratory rate, build, skin, hair, tongue, eyes, nails, legs and feet etc. Systemic examination was carried out to rule out any involvement of that particular system.

Particular attention was given to know about past history of other diseases like, diabetes-mellitus, hypertension. Addison's-disease, Cushing's-syndrome, PCOS, IHD, phaechromocytoma, liver, kidney, spleen, intestinal diseases. etc. After history taking, a complete general and systemic examination was done for any findings.

\section{INVESTIGATIONS}

A set of investigations were carried out in all the patients to include or exclude from the study and to assess the efficacy and effect of test and control drug on different parameters which included:

- Complete Blood Counts (CBC)

- Erythrocyte Sedimentation rate (ESR)

- Fasting Blood Sugar (FBS)

- Lipid Profile

- $\quad$ Liver Function Test (LFT)

- Kidney function test (KFT)

- Urine examination

- $\quad$ E. C. G.

- $\quad$ Thyroid function test (TSH, T4, T3)

All the above mentioned investigations were carried out in all patients the before the commencement of the study and after the completion of the study. 


\section{Consent of the Patient}

Before enrolling the patients for the study, every patient was provided a set of specially designed Information Consent Form (ICF) which included all the relevant information about the study with all the options to ask any query regarding the study.

\section{Assessment of Mizaj (Temperament)}

Temperament of each patient was assessed as per the specially designed questionnaire format prepared by Central Council for Research in Unani Medicine (CCRUM), Ministry of AYUSH, Govt. of India.

\begin{tabular}{|c|c|c|c|c|c|c|c|c|}
\hline \multirow{2}{*}{$\begin{array}{l}\text { PARAMETERS } \\
\text { COMPLEXION }\end{array}$} & \multicolumn{2}{|l|}{$\begin{array}{l}\text { DAMVI } \\
\text { (Sanguine) }\end{array}$} & \multicolumn{2}{|l|}{$\begin{array}{l}\text { BALGHAMI } \\
\text { (Phlegmatic) }\end{array}$} & \multicolumn{2}{|l|}{$\begin{array}{l}\text { SAFRAVI } \\
\text { (Bilious) }\end{array}$} & \multicolumn{2}{|l|}{$\begin{array}{l}\text { SAWDAWI } \\
\text { (Melancholic) }\end{array}$} \\
\hline & $\begin{array}{l}\text { Ruddy (Reddish/ } \\
\text { wheaty/ } \\
\text { brown) }\end{array}$ & 1 & $\begin{array}{l}\text { Chalky } \\
\text { (Whitish) }\end{array}$ & 0.75 & $\begin{array}{l}\text { Pale } \\
\text { (Yellowish) }\end{array}$ & 0.5 & $\begin{array}{l}\text { Purple } \\
\text { (Blackish) }\end{array}$ & 0.25 \\
\hline BUILT & Muscular \& Broad & 1 & Fatty \& Broad & 0.75 & $\begin{array}{l}\text { Muscular \& } \\
\text { Thin }\end{array}$ & 0.5 & Skeletal & 0.25 \\
\hline TOUCH & Hot \& Soft & 1 & Cold \& Soft & 0.75 & Hot \& Dry & 0.5 & Cold \& Dry & 0.25 \\
\hline HAIR & $\begin{array}{l}\text { Black \& lusty thick. } \\
\text { Rapid Growth. }\end{array}$ & 1 & $\begin{array}{l}\text { Black \& thin. } \\
\text { Slow Growth. }\end{array}$ & 0.75 & $\begin{array}{l}\text { Brown \& Thin. } \\
\text { Rapid Growth }\end{array}$ & 0.5 & $\begin{array}{l}\text { Brown \& } \\
\text { Thin. Slow } \\
\text { Growth. }\end{array}$ & 0.25 \\
\hline MOVEMENT & Active & 1 & Dull & 0.75 & Hyperactive & 0.5 & Less Active & 0.25 \\
\hline $\begin{array}{l}\text { DIET (Most } \\
\text { Liked) }\end{array}$ & Cold \& Dry & 1 & Hot \& Dry & 0.75 & Cold \& Moist & 0.5 & Hot \& Moist & 0.25 \\
\hline $\begin{array}{l}\text { WEATHER } \\
\text { (Most Suitable) }\end{array}$ & Spring & 1 & Summer & 0.75 & Winter & 0.5 & Autumn & 0.25 \\
\hline SLEEP & Normal (6-8 hrs.) & 1 & In excess & 0.75 & Inadequate & 0.5 & Insomnia & 0.25 \\
\hline PULSE & Normal (70-80/min) & 1 & Slow (60-70) & 0.75 & Rapid (80-100) & 0.5 & Slow (60-70) & 0.25 \\
\hline EMOTIONS & Normal & 1 & Calm \& quiet & 0.75 & Angry & 0.5 & Nervous & 0.25 \\
\hline
\end{tabular}

Total $=$

Range of temperament in numbers

Sanguine: 7.5-10; Phlegmatic: 5.10-7.50; Bilious: 2.515.00: Melancholic: $0.00-2.50$

\section{Damvi}

\section{Balghami}

Safravi

\section{Sawdawi}

\section{RESULTS AND OBSERVATION}

On assessment of Mizaj of patients of Hypothyroidism by specially designed format the result showed that out of 60 patients enrolled for the study, 52 patients were balghami mizaj $(86.6 \%), 05$ patients were safravi mizaj (8.3\%), 03 were damvi mizaj (5\%) and none of the 60 patients enrolled for the study was Sawdawi mizaj. Hence, it became evident that Hypothyroidism is a balghami mar'd (Phelgematic disease) and it mostly affects people with barid wa ratabb mizaj (cold and moist temperament).

Table-1: Showing age of patients $(\%)$ in Hypothroidism $\mathrm{N}=60$

\begin{tabular}{|l|l|l|l|}
\hline S. No & Age in Years & Number & Percentage \\
\hline $\mathbf{1}$ & $20-30$ & 9 & 15 \\
\hline $\mathbf{2}$ & $31-40$ & 16 & 26.66 \\
\hline $\mathbf{3}$ & $41-50$ & 20 & 33.33 \\
\hline $\mathbf{4}$ & $51-60$ & 15 & 25 \\
\hline & TOTAL & $\mathbf{6 0}$ & $\mathbf{1 0 0}$ \\
\hline
\end{tabular}

Table-2: Showing Sex distribution in patients $(\%)$ of Hypothroidism $\mathrm{N}=60$

\begin{tabular}{|l|l|l|l|}
\hline S. No & SEX & Number & Percentage \\
\hline $\mathbf{1}$ & Male & 13 & 21.66 \\
\hline $\mathbf{2}$ & Female & 47 & 78.33 \\
\hline & TOTAL & $\mathbf{6 0}$ & $\mathbf{1 0 0}$ \\
\hline
\end{tabular}

Table-3: Showing Mijaz in patients (\%) of Hypothyroidism $\mathrm{N}=60$

\begin{tabular}{|l|l|l|l|}
\hline S. No & Mizaj & Number & Percentage \\
\hline $\mathbf{1}$ & Balghami & 52 & 86.6 \\
\hline $\mathbf{2}$ & Damvi & 3 & 5 \\
\hline $\mathbf{3}$ & Safravi & 5 & 8.3 \\
\hline $\mathbf{4}$ & Sawdawi & 0 & 0 \\
\hline & TOTAL & $\mathbf{6 0}$ & $\mathbf{1 0 0}$ \\
\hline
\end{tabular}

\section{REFERENCES}

1. Gregory, A. B., \& Anthony, P. W. (2016). Hypothyroidism and Thyroiditis, Williams textbook of Endocrinolgy, 13th ed. RELX India. Pvt. Ltd. 416-444.

2. Vaidya, B., \& Pearce, S. H. (2008). Management of hypothyroidism in adults. Bmj, 337:a801.

3. Almandoz, J. P., \& Gharib, H. (2012). Hypothyroidism: etiology, diagnosis, and management. Medical Clinics, 96(2), 203-221.

4. Caturegli, P., De Remigis, A., \& Rose, N. R. (2014). Hashimoto thyroiditis: clinical and diagnostic criteria. Autoimmunity reviews, 13(45), 391-397.

5. Persani, L. (2012). Clinical review: central hypothyroidism: pathogenic, diagnostic and 
therapeutic challenges. J Clin Endocrinol Metab. 97:3068-3078.

6. Jabbar, P. K., \& Danish, E. (2012). Hypothyroidism: Introduction, etiology and clinical features. ITS Clinical Manual of Thyroid Disorders, Jayakumar, R. V. First ed. Elsevier Limited: 129-30.

7. Gull, W. W. (1874). On a cretinoid state supervening in adult life in women. Trans Clin Soc London. 7:180.

8. Report of a Committee of the Clinical Society of London to Investigate the subject of Myxedema. London longmans. Green \& Co. Ltd. 1888.

9. Wilkinson, R., Wiles, G., \& O’Neil, H. (2017). Oxford Handbook of Clinical Medicine, International Edition, $10^{\text {th }}$ ed. Oxford University Press. 22039.

10. Jayakumar, R. V. (2012). Oomen Tittu, Thyroid hormone; Physiology and mechanism of action. ITS Clinical Manual of Thyroid Disorders, RV Jayakumar, First ed. Elsevier Limited. 11-14.

11. Benvenga, S. (2005). Thyroid hormone transport proteins and the physiology of hormone binding. In: The thyroid: Fundamental and Clinical Text $9^{\text {th }}$ ed, Braveman, L. E., \& Utiger, R. D., eds. Lippincott Williams and Wilkins: Philadelphia. 97.

12. Magner, J. A. (1990). Thyroid-stimulating hormone: biosynthesis, cell biology and bioactivity. Endocr Rev, 11:354-85.

13. Guyton, C. (1987). Effect of Thyroid hormone on specific bodily mechanism. Prism Books pvt Ltd. Banglore-India. $8^{\text {th }}$ ed. (1991):835-3655.

14. Baghdadi, H. (2005). Kitab al- Mukhtar'at Fi'l Tibb. (Urdu Translation). CCRUM New Delhi. Vol.-1. Model Offset Works. Jamia Masjid Delhi. 155.

15. Razi, Z. (1991). Kitab al- Mansuri (Urdu Translation). CCRUM-New Delhi. 76.

16. Avicenna. (2007). The Canon of Medicine. (English Translation by Mazhar H. Shah). Idara Kitabul Shifa, Kucha chelan Darya Ganj. New Delhi. 225.

17. Majoosi, A. (1889). Kamil al- Sana't (Urdu Translation by Kantoori GH) Vol.1. Lucknow: Munshi Nawal Kishore. 25,28,426.

18. Usmani, S. (2005). Mizaj al-Insane Tehqeeqi Mutala. Jahane Tibb. 7(2):34-36.

19. Kirmani N. B. A. Kulliyat al- Nafeesi (Urdu Translation by Kabeer uddin) Vol.1. New Delh; Idara Kitabul Shifaa; New Delhi: 697-705.

20. Tabri, R. (2010). Firdous al- Hikmah (Urdu Translation). New Delhi: Idara Kitabul Shifaa; New Delhi, 52:89-90. Melmed, Polonsky, Larsen, Kronenberg. Williams Text Book of
Endocrinology.13th ed. RELX India. Pvt. Ltd. 2016:2-4.

21. Jabbar, P. K., \& Danish, E. (2012). Hypothyroidism: Introduction, etiology and clinical features. ITS Clinical Manual of Thyroid Disorders, Jayakumar, R. V. First ed. Elsevier Limited: 129-30.

22. Liu, Y. Y., \& Brent, G. A. (2010). Thyroid hormone crosswalk with nuclear receptor signaling in metabolic regulation. Trends Endocrinol Metab, 21:166-73.

23. Smith, T. J., Bahn, R. S., \& Gorman, C. A. (1989). Connective tissue, glycosaminoglycans and diseases of the thyroid. Endocr Rev, 10:366-91.

24. Baurer, M., Goetz, T., Glenn, T., \& Whybrow, P. C. (2008). The thyroid brain interaction in thyroid disorders and mood disorders. J Neuroendocrin, 20:1101-14.

25. Bland, J. H., \& Frymoyer, J. W. (1970). Rheumatic syndromes of myxedema. N Engl J Med, 282:1171-4.

26. Klein, I., \& Danzi, S. (2007). Thyroid disease and the heart. Circulation. 116:1725-35.

27. Redmond, G. P. (2004). Thyroid dysfunction and women's reproductive health. Thyroid. 14 (Suppl 1):S5-15.

28. Krassas, G. E., Tziomalos, K., Papadopoulou, F., Pontikides, N., \& Perros, P. (2008). Erectile dysfunction in patients with hyper-and hypothyroidism: how common and should we treat?. The Journal of Clinical Endocrinology \& Metabolism, 93(5), 1815-1819.

29. Kamilaris, T. C., Debold, C. R., Pavlou, S. N., Island, D. P., Hoursanidis, A., \& Orth, D. N. (1987). Effect of altered thyroid hormone levels on hypothalamic-pituitary-adrenal function. The Journal of Clinical Endocrinology \& Metabolism, 65(5), 994-999.

30. Kahaly, G. J., \& Dillmann, W. H. (2005). Thyroid hormone action in the heart. Endocrine reviews, 26(5), 704-728.

31. Combs, C. E., Nicholls, J. J., Duncan Bassett, J. H., \& Williams, G. R. (2011). Thyroid hormones and bone development. Minerva Endocrinol, 36(1), 71-85.

32. Kalminjin, S., Mehta, K. M., \& Pols, H. A. (2005). Subclinical hypothyroidism and risk of dementia. The Rottardam study. Clin Endocrinol (Oxf). 53:733-737.

33. Joffe, R. T., Pearce, E. N., Hennessey, J. V., Ryan, J. J., \& Stern, R. A. (2013). Subclinical hypothyroidism, mood, and cognition in older adults: a review. International journal of geriatric psychiatry, 28(2), 111-118. 